\title{
Progressive bladder remodeling due to bladder outlet obstruction: a systematic review of morphological and molecular evidences in humans
}

\author{
Ferdinando Fusco ${ }^{1 *}$ D, Massimiliano Creta ${ }^{1}$, Cosimo De Nunzio², Valerio lacovelli ${ }^{3}$, Francesco Mangiapia', \\ Vincenzo Li Marzi ${ }^{4}$ and Enrico Finazzi Agrò ${ }^{3}$
}

\begin{abstract}
Background: Bladder outlet obstruction is a common urological condition. We aimed to summarize available evidences about bladder outlet obstruction-induced molecular and morphological alterations occurring in human bladder.

Methods: We performed a literature search up to December 2017 including clinical and preclinical basic research studies on humans. The following search terms were combined: angiogenesis, apoptosis, bladder outlet obstruction, collagen, electron microscopy, extracellular matrix, fibrosis, hypoxia, histology, inflammation, innervation, ischemia, pressure, proliferation, remodeling, suburothelium, smooth muscle cells, stretch, urothelium.

Results: We identified 36 relevant studies. A three-stages model of bladder wall remodeling can be hypothesized involving an initial hypertrophy phase, a subsequent compensation phase and a later decompensation. Histological and molecular alterations occur in the following compartments: urothelium, suburothelium, detrusor smooth muscle cells, detrusor extracellular matrix, nerves. Cyclic stretch, increased hydrostatic and cyclic hydrodynamic pressure and hypoxia are stimuli capable of modulating multiple signaling pathways involved in this remodeling process.
\end{abstract}

Conclusions: Bladder outlet obstruction leads to progressive bladder tissue remodeling in humans. Multiple signaling pathways are involved.

Keywords: Bladder outlet obstruction, Bladder remodeling, Systematic review

\section{Background}

Bladder outlet obstruction (BOO), clinically defined as highpressure/low-flow micturition pattern at urodynamic investigations, is a common urological condition in humans with benign prostatic obstruction (BPO) being the most frequent causative factor. It represents a key pathophysiological link between benign prostate enlargement (BPE) and lower urinary tract symptoms (LUTS) [1-3]. Besides symptoms, BOO can also lead to progressive tissue remodeling of the bladder and of the upper urinary tract with subsequent serious

\footnotetext{
* Correspondence: ferdinando-fusco@libero.it

'Dipartimento di Neuroscienze e Scienze Riproduttive ed

Odontostomatologiche, Università Degli Studi Di Napoli Federico II, Via

Pansini, 5, 80131 Naples, Italy

Full list of author information is available at the end of the article
}

functional impairments [1-4]. Based on the results from studies on animal models exposed to experimental partial outlet obstruction, the remodeling of the bladder involves the modulation of several signaling pathways as well as histological alterations occurring in almost all cellular compartments [5]. These changes are described to progress through three sequential stages: hypertrophy, compensation and decompensation [6]. In the hypertrophy stage, mechanical stress activates early signals that mediate bladder wall hypertrophy. At the same time, due to the occurrence of focal area of hypoxia, angiogenesis is stimulated thus enabling blood flow to increase relative to bladder mass [6]. In the compensated stage bladder growth and angiogenesis stop. At some point, if obstruction persists, the bladder shifts to a decompensated state as a result of cyclical 
ischemia-reperfusion injury occurring during the micturition phase that leads to the activation of pathways involved in the progressive loss of smooth muscle, deposition of extracellular matrix and neuronal loss [6]. The duration of these stages varies considerably according to the experimental models and is unpredictably. Data about the reversibility of these alterations are also lacking. Human detrusor differs significantly from animal models and most of the species used for research don't suffer from naturally occurring outflow obstruction [7]. The aim of the present study was to summarize available evidences about BOO-induced morphological and molecular alterations occurring in the various compartments of human bladder.

\section{Methods}

We performed a systematic review using the Preferred Reporting Items for Systematic Reviews and Meta-Analyses Statement as a guideline in the development of the study protocol and the report of the current study [8]. In December 2017 we used the National Library of Medicine PubMed search engine, the Scopus database, and the ISI Web of Knowledge official website to search for all published studies evaluating morphological and molecular alterations involved in BOO-induced bladder wall remodeling. The following search terms were combined: angiogenesis, apoptosis, bladder outlet obstruction, collagen, electron microscopy, extracellular matrix, fibrosis, hypoxia, histology, inflammation, innervation, ischemia, pressure, proliferation, remodeling, suburothelium, smooth muscle cells, stretch, urothelium. We included publications that met the following criteria: reporting original in vitro and in vivo research; English language; human studies. Reference lists in relevant articles and reviews were also screened for additional studies.

\section{Results}

The search strategy revealed a total of 159 results. Screening of the titles and abstracts revealed 44 papers eligible for inclusion. Further assessment of eligibility, based on full-text papers, led to the exclusion of 8 papers. This left 36 papers meeting our criteria for inclusion [9-44] (Fig. 1).

\section{Alterations occurring in the urothelium and suburothelium} We identified one study describing BOO-induced alterations occurring in the context of urothelium and suburothelium [9]. Bladder biopsies were obtained from 33 men with urodynamic proven $\mathrm{BOO}$ and 10 control subjects. Authors demonstrated the occurrence of significant urothelial dysfunction and alterations of urothelial signaling and sensory transduction pathways in patients with BOO. In detail, the following alterations were found: significantly lower expression of the adhesion protein Ecadherin and of the muscarinic receptor M3, and significantly higher expression of the purinergic receptor P2X3 and of the muscarinic receptor M2. Interestingly, patients with detrusor underactivity had a significantly lower expression of E-cadherin and of inducible nitric oxide synthase as well as a significantly higher expression of $\beta 3$ adrenoreceptors than patients with detrusor overactivity/ hypersensitive bladder. Clinically, lower expression of Ecadherin was associated with lower voided volumes thus suggesting a more severe or decompensated status with more severe urothelial dysfunction. Alterations found in the suburothelium of $\mathrm{BOO}$ patients included: inflammation, with a significantly increased level of activated mast cells, and increased apoptosis.

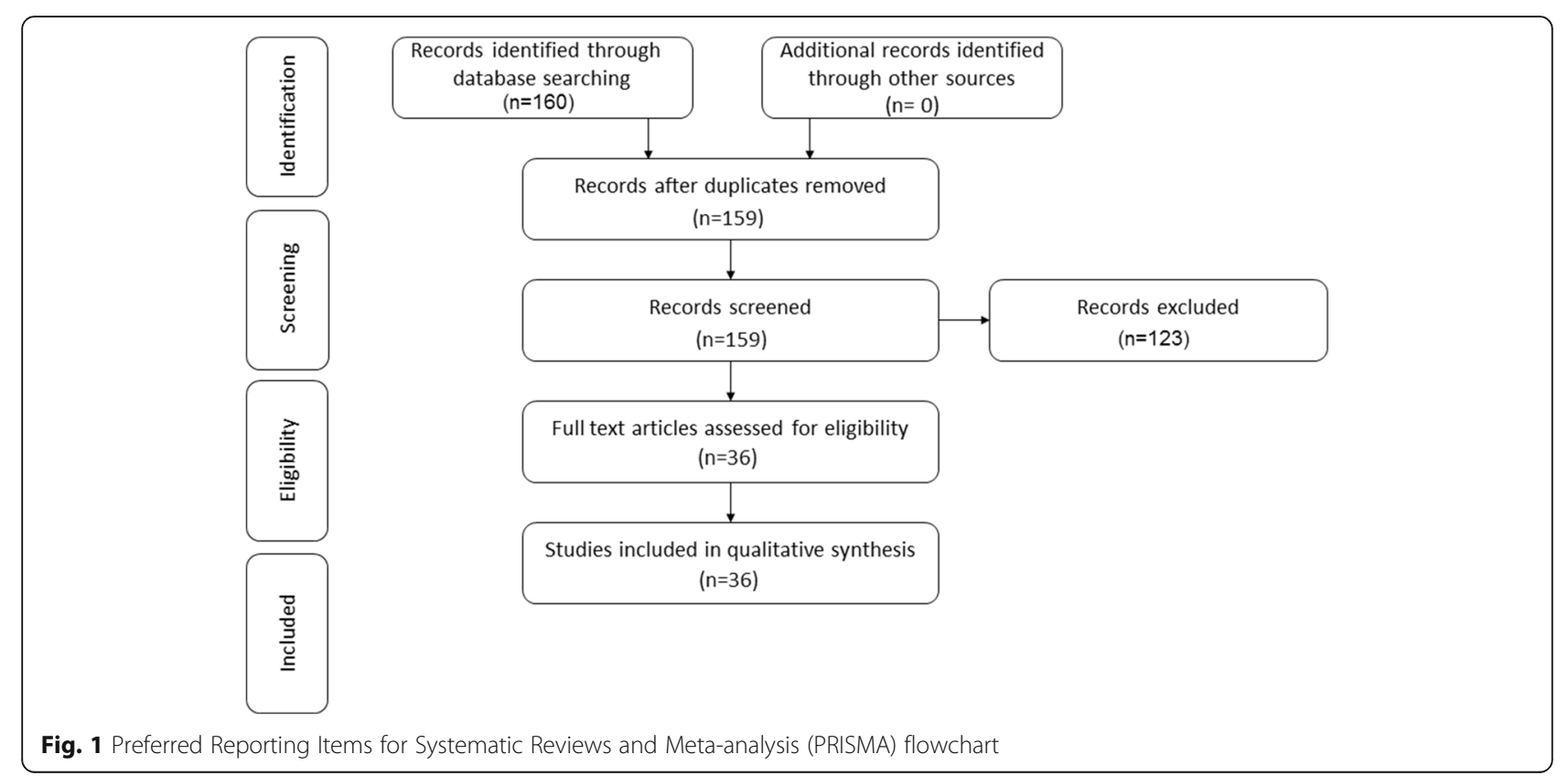




\section{Alterations occurring in the detrusor muscle: morphological aspects}

The detrusor muscle represents the bladder compartment more extensively investigated. Studies describing BOO-induced morphological alterations occurring in the detrusor are summarized in Table 1. Significant alterations involving both smooth muscle cells (SMCs) and extracellular matrix (ECM) have been demonstrated using light and electron microscopy studies.

\section{SMCs alterations}

Detrusor SMCs hypertrophy represents the most relevant morphological alteration occurring in $\mathrm{BOO}$ patients. Gilpin et al. compared the morphological and morphometric characteristics of detrusor specimens from patients with unequivocal urodynamic BOO accompanied by evidence of severe bladder trabeculation at cystoscopy and subjects with normal urodynamic assessment and absent trabeculation [10]. Although authors did not find morphological evidences of SMCs hyperplasia, the mean profile

Table 1 Summary of studies describing BOO-induced detrusor morphological alterations

\begin{tabular}{|c|c|c|c|}
\hline Author, year & Study design & Subjects in the case group (n) & Main findings \\
\hline Gosling, 1980 [15] & Case control & 9 & $\begin{array}{l}\cdot \uparrow \text { intrafascicular and interfascicular collagen } \\
\cdot \downarrow \text { SMCs diameter }\end{array}$ \\
\hline Gilpin, 1985 [10] & Case control & 14 & $\begin{array}{l}\text { - } \uparrow \text { connective tissue infiltration of some smooth } \\
\text { muscle bundles in } 12 / 14 \text { patients } \\
\text { - } \uparrow \text { SMCs mean profile area }\end{array}$ \\
\hline Elbadawi, 1993 [12] & Case control & 7 & $\begin{array}{l}\text { - } \downarrow \text { intermediate cell junctions } \\
\text { - } \text { intrafascicular collagen and elastic fibers } \\
\text { - } \uparrow \text { SMCs hypertrophy } \\
\text { - } \uparrow \text { SMCs and axons degeneration in patients with } \\
\text { impaired detrusor contractility }\end{array}$ \\
\hline Inui, 1999 [19] & Case control & 26 & $\begin{array}{l}\text { - Significant positive linear relationship between C/M } \\
\text { and estimated bladder weight in patients with } \\
\text { bladder weight } \geq 60 \mathrm{~g} \\
\text { - } \uparrow \mathrm{C} / \mathrm{M} \text { in patients with bladder weight } \geq 60 \mathrm{~g}\end{array}$ \\
\hline Tse, 2000 [13] & Case control & 9 & - Myohypertrophy pattern in all cases \\
\hline Brierly, 2003 [14] & Case control & 12 & $\begin{array}{l}\text { - Myohypertrophy pattern in 8/10 BOO patients. } \\
\text { - Degenerative pattern in 4/10 BOO patients. }\end{array}$ \\
\hline Holm, 2003 [22] & Case control & 25 & $\begin{array}{l}\text { - Significant correlation between intra- and } \\
\text { interfascicular elastin and BOO degree }\end{array}$ \\
\hline Mirone, 2004 [15] & Case control & 36 & $\begin{array}{l}\text { - } \uparrow \text { collagen content in BPO patients with } \\
\text { respect to controls } \\
\text { - } \uparrow \text { collagen content in patients with severe symptoms }\end{array}$ \\
\hline Horn, 2004 [44] & Observational & 54 & $\begin{array}{l}\text { - Correlation between abnormal morphology and } \\
\text { impaired bladder compliance and decreased capacity }\end{array}$ \\
\hline Collado, 2006 [11] & Case control & 33 & $\begin{array}{l}\text { - } \uparrow \text { intrafascicular and interfascicular collagen } \\
\text { - } \uparrow \text { intrafascicular fibrosis in BOO patients with } \\
\text { history of AUR } \\
\text { - } \uparrow \text { SMCs diameter in BOO patients with } \\
\text { respect to controls } \\
\text { - Not significant differences in terms of SMCs diameter } \\
\text { between BOO patients with and without AUR history } \\
\text { - Positive correlation between SMCs diameter and } \\
\text { symptoms duration }\end{array}$ \\
\hline Rubinstein, 2007 [18] & Case control & 10 & - $\uparrow$ collagen and elastic fibers \\
\hline Blatt, 2012 [16] & Case control & 17 & $\begin{array}{l}\text { - Poor post-TURP voiding outcome in patients with } \\
\text { detrusor ultrastructural pattern characterized by } \\
\text { variable muscle cell size, muscle cell shape, abnormal } \\
\text { fascicle arrangement and collagenosis. }\end{array}$ \\
\hline Bellucci, 2017 [21] & Case control & 19 & $\begin{array}{l}\text { - } \uparrow \mathrm{C} / \mathrm{M} \\
\text { - Significant negative correlation between C/M and } \\
\text { bladder compliance } \\
\text { - Significant correlation between the probability of } \\
\text { urinary retention and C/M }\end{array}$ \\
\hline Averbeck, 2017 [20] & Observational & 38 & $\begin{array}{l}\text { - } \uparrow \mathrm{C} / \mathrm{M} \text { in patients with } \mathrm{PVR} \geq 200 \mathrm{~mL} \text { and in those } \\
\text { with reduced bladder compliance }\end{array}$ \\
\hline
\end{tabular}

AUR acute urinary retention, $B O O$ bladder outlet obstruction, $C / M$ connective tissue-to-smooth muscle ratio, $P V R$ post void residual volume, SMCS smooth muscle cells, TURP trans urethral resection of the prostate 
area of SMCs was higher in BOO patients due to hypertrophy. Similarly, Collado et al. demonstrated that detrusor SMCs diameter was significantly higher in $\mathrm{BOO}$ patients with respect to controls [11]. Authors found a positive correlation between SMCs diameter and symptoms duration but no statistically significant differences between $\mathrm{BOO}$ patients with and without history of Acute Urinary Retention (AUR). Electron microscopy studies also confirmed the evidence of SMCs hypertrophy in many cases. Elbadawi et al. investigated the ultrastructural basis of obstructive detrusor dysfunction in a prospective case-control study enrolling 35 elderly subjects [12]. Authors described the "myohypertrophy" structural pattern in patients with urodynamic proven BOO. This pattern was characterized by 4 distinctive features, including SMCs hypertrophy, marked widening of intercellular spaces with reduced normal intermediate cell junctions, increased deposition of collagen and elastin between SMCs, and patchy distribution of the preceding features in various muscle fascicles. This ultrastructural pattern was confirmed by other authors in patients with urodynamic evidence of $\mathrm{BOO}[13,14]$. Of note, the evidence of SMCs hypertrophy has not been confirmed in all patients. In their light microscopy study, Gosling et al. failed to found evidences of SMCs hypertrophy or hyperplasia in a subset of patients with unequivocal BPO accompanied by trabeculated urinary bladder [15]. On the contrary, authors identified some muscle bundles containing SMCs characterized by a small diameter [15]. Elbadawi et al. showed degeneration of SMCs in the specimens of patients who had impaired detrusor contractility [12]. The degenerative pattern was confirmed by Brierly et al. in BOO patients with high post void residual volume [14].

\section{ECM alterations}

Detrusor ECM remodeling is characterized by increased accumulation of collagen and elastic fibers in both the interfascicular and intrafascicular compartments. This finding has been confirmed in several studies using both light and electron microscopy techniques [10, 11, 1521]. Interestingly, Gilpin et al. found that patients with evidence of interfascicular connective tissue infiltration had the highest levels of SMCs mean profile area thus leading the authors to hypothesize that the deposition of connective tissue occurs at a later stage with respect to onset of SMCs hypertrophy [10]. This hypothesis has been confirmed by other studies. Inui et al. investigated the relationship between the amount of detrusor connective tissue in patients with $\mathrm{BPH}$ and the degree of bladder hypertrophy evaluated by ultrasound estimated bladder weight. In detail, authors compared the ratio of connective tissue-to-smooth muscle $(\mathrm{C} / \mathrm{M})$ between controls and BPE cases [19]. The study failed to found statistically significant differences between the two groups
(27.3\% in BPE patients and $24.7 \%$ in controls). However, a significant positive linear relationship between $\mathrm{C} / \mathrm{M}$ and estimated bladder weight was evident in all BPE patients with estimated bladder weight $\geq 60 \mathrm{~g}$ [19]. Interestingly, $30 \%$ of BPE patients had $\mathrm{C} / \mathrm{M}<20 \%$ compared to only $7.7 \%$ of controls. Author hypothesized that the increase in ultrasound estimated bladder weight is caused at early stages by hyperplasia and/or hypertrophy of detrusor SMCs leading to a lower $\mathrm{C} / \mathrm{M}$ and later to the additional increase of connective tissue with higher $\mathrm{C} / \mathrm{M}$. Other studies confirmed the occurrence of increased detrusor ECM accumulation with more advanced stages within the natural history of $\mathrm{BOO}$. Collado et al. compared detrusor $\mathrm{C} / \mathrm{M}$ of patients with urodynamic $\mathrm{BOO}$ and no history of AUR, patients with urodynamic $\mathrm{BOO}$ and history of AUR and nonobstructed controls [11]. Patients with BOO (obstruction and AUR groups) had a significantly higher intrafascicular and interfascicular collagen content than the control group. Patients with history of AUR had statistically significant higher levels of intrafascicular collagen than BOO patients without history of AUR. Moreover, authors found a statistically significant correlation between the amount of intrafascicular fibrosis and detrusor pressure at maximum urinary flow as well as with the Abrams-Griffiths number in $\mathrm{BOO}$ patients without history of AUR at pre-operative urodynamics. Additionally, a statistically significant negative correlation was found between intrafascicular fibrosis and postoperative bladder compliance in the same group of patients. Finally, a positive and significant correlation was found between intrafascicular fibrosis and both detrusor pressure at maximum urinary flow and the Abrams-Griffiths number in BOO patients with history of AUR at postoperative urodynamic evaluation [11]. Averbeck et al. evaluated the collagen content in the bladder wall of men undergoing open prostate surgery. Although BOO was not a predictor of increased collagen deposition, patients with reduced bladder compliance and those with a $P V R \geq 200 \mathrm{~mL}$ showed a significantly higher C/M [20]. Similarly, Bellucci et al. found a significant negative correlation between $\mathrm{C} / \mathrm{M}$ and bladder compliance [21]. Moreover, the probability of urinary retention increased significantly with the $\mathrm{C} / \mathrm{M}$. Mirone et al. found higher detrusor collagen content in patients with $\mathrm{BPO}$ and severe symptoms with respect to patients with moderate symptoms [22]. Blatt et al. investigated the correlation between detrusor ultrastructural features of patients with urodynamic $\mathrm{BOO}$ or a hypocontractile detrusor and clinical outcomes after transurethral resection of the prostate [16]. Authors found that the morphological pattern characterized by variable SMCs size, SMCs shape, abnormal fascicle arrangement and collagenosis correlated with poor postoperative voiding outcome. Holm et 
al. investigated the correlation between ultrastructural findings and urodynamic parameters in patients with BOO [17]. SMCs hypertrophy, occurrence of abnormal cell junctions and configurations, variation in intercellular distances, and intracellular changes were investigated. The increase in intra- and interfascicular elastin was only parameter which was found to relate to the degree of obstruction in BOO patients.

\section{Alterations occurring in the detrusor muscle: molecular aspects and signaling pathways}

Data about molecular aspects and signaling pathways involved in BOO-induced detrusor remodeling mainly derive from in vitro cell culture models of human bladder SMCs (HBSMCs) exposed to stressful stimuli such as cyclic mechanical stretch, increased hydrostatic (HP) or cyclic hydrodynamic pressure (CHP), and hypoxia. Further evidences derive from genetic and molecular studies on tissue specimens from BOO patients. Table 2 summarizes evidences from these studies.

\section{Effects of cyclic stretch}

Yang et al. investigated the effects of cyclic stretch on HBSMCs gene expression [23]. Authors identified multiple mechano-responsive genes encoding cytokine, growth-related factors, adhesive molecules, signal transduction molecules, cytoskeleton and extracellular matrix proteins, developmental, differentiation, and inflammatory factors. Twelve of proteins encoded by these genes had interacting partners in the vascular system and were functionally involved in multiple aspects of angiogenesis and vascular development such as endothelial cell proliferation and migration, SMCs differentiation, and arterial-venous differentiation.

\section{Effects of increased pressure}

The effects of increased pressure on HBSMCs has been investigated by many authors. These studies demonstrated the existence of multiple pressure-dependent pathways involved into cellular processes such as adhesion, proliferation, inflammation, and ECM remodeling.

\section{Effects of increased pressure on cell adhesion}

Wang et al. demonstrated a significant decreased expression of the gap junction connexin 43 under hydrostatic pressures $>60 \mathrm{~cm} \mathrm{H}_{2} \mathrm{O}$ for $24 \mathrm{~h}$ or pressures $>40 \mathrm{~cm}$ $\mathrm{H}_{2} \mathrm{O}$ for $72 \mathrm{~h}[24]$.

\section{Effects of increased pressure on cell hypertrophy and hyperplasia}

Lee et al. investigated the effects of HP on HBSMCs in terms of cell hypertrophy and hyperplasia and the potential role of muscarinic receptors [26]. HBSMCs proliferation and hypertrophy were measured by $3 \mathrm{H}$-thymidine and leucine incorporation assays, respectively [25]. 3Hthymidine incorporation increased by 16.7, 25.9 and $39.4 \%$ after exposure to acetylcholine, $40 \mathrm{cmH}_{2} \mathrm{O} \mathrm{HP}$, and both, respectively. Similarly, leucine incorporation increased by $66.5,66.5$ and $81.8 \%$, after exposure to acetylcholine, $40 \mathrm{cmH}_{2} \mathrm{O} \mathrm{HP}$, and both, respectively. These findings were consistent with increased proliferation and hypertrophy, respectively. Antimuscarinic agents determined a dramatic decrease in thymidine and leucine incorporation for cells exposed to increased HP, most pronounced when both M2 and M3 receptor antagonist were applied. In a subsequent study, authors found that M2 and M3 receptor expression increases in a time- and pressure-dependent manner in isolated HBSMCs [26]. Preis et al. investigated the role of platelet derived growth factor (PDGF) pathway in pressureinduced proliferation [27]. Exposure of HBSMCs to HP induced proliferation in a time dependent manner. Moreover, HBSMCs showed increased PDGF receptor (PDGFR) $\alpha$ and $\beta$ expression. Interestingly, DNA synthesis in cells with intact PDGFR $\alpha$ was increased after short-term HP but cells lacking PDGFR $\alpha$ did not proliferate. All studies evaluating the effects of CHP on HBSMCs demonstrated increased proliferation under $\mathrm{CHP}>100 \mathrm{cmH}_{2} \mathrm{O}$. Involved signaling pathways include: phosphoinositide 3-kinase/serum-glucocorticoid regulated kinase 1, S-phase kinase-associated protein 2, p27, Ras-related C3 botulinum toxin substrate 1, miR-31805p and miR 4323 [28-32]. MiR-3180-5p promotes HBSMCs proliferation by the activation of the proproliferative cyclin-dependent kinase 2 pathway [29]. On the other hand, miR 4323 can promote HBSMCs proliferation by inhibiting LYN expression and activating the Erk1/2 pathway, also known as the mitogen activated protein kinase signaling pathway [30].

\section{Effects of increased pressure on inflammatory pathways}

Liang et al. investigated the effects of HP and acetylcholine on the release of inflammatory cytokines in HBSMCs to test the hypothesis that mechanical force and muscarinic receptors have pro-inflammatory effect in obstructed bladder [33]. HP produced a significant time-dependent and pressure-dependent increase in expressions of inflammatory genes. $\mathrm{HP}$ of $200 \mathrm{~cm} \mathrm{H}_{2} \mathrm{O}$ for $24 \mathrm{~h}$ was associated with a statistically significant increase of monocyte chemoattractant protein, IL-6, and RANTES. Both NFKB and ERK1/2 pathways were proved to be involved in pressure-induced inflammation.

\section{Effects of increased pressure on ECM remodeling}

Backhaus et al. applied HP to HBSMCs to determine the effect on matrix metalloproteinases (MMPs) and tissue inhibitors of metalloproteinases (TIMP) [34]. Exposure of HBSMCs to a sustained $\mathrm{HP}$ of $20 \mathrm{~cm} \mathrm{H}_{2} \mathrm{O}$ for $7 \mathrm{~h}$ 
Table 2 Summary of studies evaluating BOO-induced molecular alterations and related cellular events in human detrusor

\begin{tabular}{|c|c|c|c|}
\hline Author, year & Experimental conditions & Molecular alteration & Cellular events \\
\hline Backhaus, 2002 [34] & $\begin{array}{l}\text { HBSMCs exposed to } \mathrm{HP}(0.3,20 \\
\left.\text { and } 40 \mathrm{~cm} \mathrm{H}_{2} \mathrm{O}\right) \text { for } 1,3,7 \text { and } 24 \mathrm{~h}\end{array}$ & $\begin{array}{l}\downarrow M M P-1,2,9 \text { after exposure } \\
\text { to } 20 \mathrm{~cm} \mathrm{H}_{2} \mathrm{O} \text { for } 7 \mathrm{~h} \\
\uparrow T I M P-1 \text { after exposure to } \\
40 \mathrm{~cm} \mathrm{H}_{2} \mathrm{O} 3,7 \text { and } 24 \mathrm{~h}\end{array}$ & \\
\hline Wang, 2013 [24] & $\begin{array}{l}\text { HBSMCs exposed to } \mathrm{HP} \\
\left(0,20,40,60,80 \text { and } 100 \mathrm{~cm} \mathrm{H}_{2} \mathrm{O}\right) \\
\text { for } 6,12,24 \text { and } 72 \mathrm{~h}\end{array}$ & $\begin{array}{l}\text { \expression of the gap junction } \\
\text { connexin } 43 \text { under } \mathrm{HP}>60 \mathrm{~cm} \mathrm{H}_{2} \mathrm{O} \\
\text { for } 24 \mathrm{~h} \text { or } \mathrm{HP}>40 \mathrm{~cm} \mathrm{H}_{2} \mathrm{O} \text { for } 72 \mathrm{~h} \text {. }\end{array}$ & \\
\hline Chen, 2012 [28] & $\begin{array}{l}\text { HBSMCs exposed to CHP } \\
\left(0,100,200 \text {, and } 300 \mathrm{~cm} \mathrm{H}_{2} \mathrm{O}\right)\end{array}$ & $\uparrow$ SGK1 expression and activity & $\begin{array}{l}\uparrow \text { proliferation in the } 200 \\
\text { and } 300 \mathrm{~cm} \mathrm{H} \mathrm{H}_{2} \mathrm{O} \text { groups }\end{array}$ \\
\hline Chen, 2014 [32] & $\begin{array}{l}\text { HBSMCs exposed to CHP } \\
\left(0,100,200 \text {, and } 300 \mathrm{~cm} \mathrm{H}_{2} \mathrm{O}\right)\end{array}$ & $\begin{array}{l}\uparrow \text { Skp2 expression and } \downarrow \text { p27 } \\
\text { expression under } 200 \text { and } 300 \\
\mathrm{CmH}_{2} \mathrm{O} \text { CHP }\end{array}$ & \\
\hline Wu, 2012 [31] & $\begin{array}{l}\text { HBSMCs exposed to CHP } \\
\text { (static, 100, 200, and } 300 \mathrm{~cm} \mathrm{H}_{2} \mathrm{O} \text { ) }\end{array}$ & $\begin{array}{l}\text { Ras-related } \mathrm{C} 3 \text { botulinum toxin } \\
\text { substrate } 1 \text {, mitogen-activated } \\
\text { protein kinase kinase } 1 / 2 \text { and } \\
\text { extracellular regulated protein } \\
\text { kinases } 1 / 2 \text { activated by } 200 \\
\text { and } 300 \mathrm{CmH}_{2} \mathrm{O} \text { CHP }\end{array}$ & $\begin{array}{l}\uparrow \text { proliferation under } 200 \\
\text { and } 300 \mathrm{cmH}_{2} \mathrm{O} \text { CHP }\end{array}$ \\
\hline Preis, 2015 [27] & $\begin{array}{l}\text { HBSMCs exposed to } \mathrm{HP} \\
\text { of } 136 \mathrm{~cm} \mathrm{H} \mathrm{H}_{2} \mathrm{O} \text { for } 1 \mathrm{~h}\end{array}$ & $\uparrow$ expression of PDGFR $a$ and $\beta$ & $\uparrow$ proliferation \\
\hline Sun, 2016 [29] & $\begin{array}{l}\text { HBSMCs exposed to CHP } \\
\text { up to } 200 \mathrm{~cm} \mathrm{H}_{2} \mathrm{O}\end{array}$ & $\uparrow \mathrm{miR}-3180-5 p$ & $\uparrow$ proliferation \\
\hline Sun, 2017 [30] & $\begin{array}{l}\text { HBSMCs exposed to CHP } \\
\text { up to } 200 \mathrm{~cm} \mathrm{H} \mathrm{H}_{2} \mathrm{O}\end{array}$ & $\uparrow \operatorname{miR} 4323$ & $\uparrow$ proliferation \\
\hline Lee, 2006 [25] & $\begin{array}{l}\text { HBSMCs exposed to HP } \\
\left(40 \mathrm{~cm} \mathrm{H}_{2} \mathrm{O}\right) \text { and/or } \\
\text { acetylcholine for } 24 \mathrm{~h}\end{array}$ & Activation of muscarinic receptors & $\begin{array}{l}\uparrow \text { proliferation } \\
\uparrow \text { hypertrophy }\end{array}$ \\
\hline Lee, 2008 [26] & $\begin{array}{l}\text { HBSMCs exposed to } \\
\text { acetylcholine in the presence } \\
\text { or absence of } \mathrm{HP} \\
\left(10,20 \text {, and } 40 \mathrm{~cm} \mathrm{H}_{2} \mathrm{O}\right)\end{array}$ & $\uparrow \mathrm{M} 2$ and $\mathrm{M} 3$ receptors expression & $\begin{array}{l}\uparrow \text { proliferation } \\
\uparrow \text { hypertrophy }\end{array}$ \\
\hline Yang, 2008 [23] & $\begin{array}{l}\text { HBSMCs exposed to cyclic } \\
\text { stretch with maximum of } 15 \% \\
\text { strain magnitude at a } \\
\text { frequency of } 0.3 \mathrm{~Hz} \text { for either } \\
1 \mathrm{~h} \text { or } 24 \mathrm{~h} \text {. }\end{array}$ & $\begin{array}{l}30 \text { genes upregulated and } 59 \\
\text { downregulated after } 1 \mathrm{~h} \text { exposure } \\
59 \text { genes upregulated and } 27 \\
\text { downregulated after } 24 \mathrm{~h} \text { exposure }\end{array}$ & \\
\hline Backhaus, 2002 [34] & $\begin{array}{l}\text { HBSMCs exposed to HP } \\
\left(0.3,20 \text { and } 40 \mathrm{~cm} \mathrm{H}_{2} \mathrm{O}\right)\end{array}$ & $\begin{array}{l}\downarrow \text { MMP-1, } 2,9 \\
\uparrow \text { TIMP-1 }\end{array}$ & \\
\hline Liang, 2017 [33] & $\begin{array}{l}\text { HBSMCs exposed to HP } \\
\left.\text { (100, 200, or } 300 \mathrm{~cm} \mathrm{H}_{2} \mathrm{O}\right) \\
\text { and/or acetylcholine }\end{array}$ & $\begin{array}{l}\uparrow I \mathrm{IL}-6, \text { monocyte chemoattractant } \\
\text { protein, and RANTES }\end{array}$ & \\
\hline Galvin, 2004 [7] & $\begin{array}{l}\text { HBSMCs exposed to } 1 \% \mathrm{O}_{2} \\
\text { tension for } 24,48,72 \text {, and } 96 \mathrm{~h}\end{array}$ & $\begin{array}{l}\uparrow \mathrm{HIF-1a} \\
\uparrow \mathrm{VEGF} \\
\uparrow \mathrm{p} 27^{\mathrm{kip} 1}\end{array}$ & $\downarrow$ proliferation \\
\hline Wiafe, 2017 [35] & $\begin{array}{l}\text { HBSMCs exposed to } 3 \% \mathrm{O}_{2} \\
\text { tension for } 2,24,48 \text {, and } 72 \mathrm{~h}\end{array}$ & $\begin{array}{l}\uparrow \mathrm{HIF1a} \text {, HIF2a, and HIF3a } \\
\uparrow V E G F \\
\uparrow T G F \beta 1 \\
\uparrow C T G F \\
\uparrow \text { collagens } 1,2,3,4 \\
\uparrow \text { fibronectin } \\
\uparrow a g g r e c a n \\
\uparrow T I M P \\
\uparrow a-\text { smooth muscle actin } \\
\uparrow \text { vimentin, } \\
\uparrow \text { desmin } \\
\uparrow T N F a, \text { IL } 1 \beta \text {, and IL } 6 \\
\downarrow \text { IL-10 }\end{array}$ & \\
\hline Boopathi, 2011 [38] & & $\uparrow$ expression of GATA- 6 in cases & \\
\hline
\end{tabular}


Table 2 Summary of studies evaluating BOO-induced molecular alterations and related cellular events in human detrusor (Continued)

\begin{tabular}{|c|c|c|c|}
\hline Author, year & Experimental conditions & Molecular alteration & Cellular events \\
\hline & $\begin{array}{l}\text { Bladder samples from subjects } \\
\text { with } \mathrm{BOO} \text { and controls }\end{array}$ & $\downarrow$ Caveolin-1 expression & \\
\hline Koritsiadis, 2008 [36] & $\begin{array}{l}\text { Bladder samples from subjects } \\
\text { scheduled for BPE-surgery and } \\
\text { controls }\end{array}$ & $\begin{array}{l}\uparrow \text { HIF-1a expression in stromal cells } \\
\text { between muscle bundles and in } \\
\text { connective tissue beneath the } \\
\text { mucosal layer }\end{array}$ & \\
\hline Barbosa, 2017 [37] & $\begin{array}{l}\text { Bladder samples from subjects with } \\
\text { obstructive BPE and controls }\end{array}$ & $\begin{array}{l}\uparrow \text { collagens I and III } \\
\downarrow \text { MMP-9 and TIMP-1 } \\
\uparrow \text { VEGF } \\
\downarrow \text { CD105 }\end{array}$ & \\
\hline Gheinani, 2017 [43] & $\begin{array}{l}\text { Bladder samples from subjects } \\
\text { with different states of urodynamic } \\
\text { defined BOO-induced bladder } \\
\text { dysfunction }\end{array}$ & $\begin{array}{l}\text { Progressive increase in the number } \\
\text { of altered mRNA and miRNAs from } \\
\text { the detrusor overactive to the } \\
\text { obstruction group to the underactive } \\
\text { detrusor groups }\end{array}$ & \\
\hline
\end{tabular}

BOO bladder outlet obstruction, BPE benign prostatic enlargement, $C H P$ cyclic hydrodynamic pressure, CTGF connective tissue transforming growth factor, $H B S M C s$ human bladder smooth muscle cells, HIF hypoxia inducible factor, HP hydrostatic pressures, IL interleukin, MMP matrix metalloproteinases, PDGFR platelet derived growth factor receptor, SGK1 serum-glucocorticoid regulated kinase 1, Skp2 S-phase kinase-associated protein 2, TGF transforming growth factor, TIMP tissue inhibitor of metalloproteinases, TNF tumor necrosis factor, VEGF vascular endothelial growth factor

resulted in a significant time dependent decrease in MMP-1, 2 and 9 activities compared to controls maintained at atmospheric pressure. TIMP-1 levels increased an average of $10 \%$ after exposure to $20 \mathrm{~cm} \mathrm{H}_{2} \mathrm{O}$. These changes became statistically significant when the cells were exposed to $40 \mathrm{~cm} \mathrm{H}_{2} \mathrm{O}$.

\section{Effects of hypoxia}

Available evidences demonstrate that hypoxia can modulate signaling pathways involved in angiogenesis, proliferation and ECM remodeling.

\section{Effects of hypoxia on hypoxia inducible factor and vascular endothelial growth factor}

Galvin et al. demonstrated significant time-dependent upregulation of hypoxia inducible factor (HIF)- $1 \alpha$ and vascular endothelial growth factor (VEGF) in HBSMCs exposed to hypoxia [7]. HIF- $1 \alpha$ expression was maximal at $72 \mathrm{~h}$ while a twofold increase in VEGF production was evident after $24 \mathrm{~h}$ of hypoxia and this increase continued in a time-dependent manner. Wiafe et al. investigated the effects of hypoxia on HIF $1 \alpha, \operatorname{HIF} 2 \alpha, \operatorname{HIF} 3 \alpha$ and VEGF expression [35]. Transcription of HIF1 $\alpha$ and HIF $2 \alpha$ demonstrated a time-dependent increased expression and were transiently upregulated in response to short-term hypoxia (2-24 h). HIF3 $\alpha$ genes and protein were significantly expressed after $72 \mathrm{~h}$ of hypoxia when HIF1 and HIF2 $\alpha$ proteins had resumed normoxic control levels. VEGF mRNA increased significantly after 24 and $72 \mathrm{~h}$. The up-regulation of HIF and VEGF has been confirmed in bladder specimens from LUTS/BPE subjects. Koritsiadis et al. compared the expression of HIF1alpha and carbonic anhydrase IX, a further cellular marker of hypoxia, in detrusor tissue retrieved from patients scheduled for surgery to treat BPE and controls [36]. The mean number of total cells immunoreactive to HIF- $1 \alpha$ in the study group was significantly higher with respect to the control group. HIF-1 $\alpha$ was expressed mainly in stromal cells between muscle bundles and in connective tissue beneath the mucosal layer, while urothelium and detrusor had no immunoreactivity [36]. Interestingly, the HIF- $1 \alpha$ response was limited in a timedependent manner. Indeed, the probability of HIF- $1 \alpha$ immunoreactivity was four times greater in men with $\mathrm{BOO}$ for $<10$ years, than in those with $\mathrm{BOO}$ for $>$ 10 years with an odds ratio of 4.25 thus suggesting that the bladder can compensate for the first few years after that the adaptive response declines [36]. Moreover, the risk of identifying a high expression of HIF-1 $\alpha$ was four times higher in patients with urinary retention [36]. Barbosa et al. compared the gene expression of the angiogenic growth factor VEGF in bladder specimens from patients with obstructive $\mathrm{BPH}$ with grade IV or higher BOO as per Schäfer criteria and age-matched controls [37]. Patients with BOO presented a statistically significant overexpression of VEGF. Interestingly, upregulation of VEGF was particularly evident in subjects with risk factors for atherosclerosis.

\section{Effects of hypoxia on HBSMCs proliferation}

Galvin et al. demonstrated that HBSMCs exposed to hypoxia maintain their cell viability in culture and do not undergo cell death when placed under hypoxic conditions [7]. However, hypoxia significantly reduces the rate of proliferation in a time-dependent manner, associated with an increase in the cell cycle inhibitor p27 ${ }^{\mathrm{kip} 1}[7]$. 


\section{Effects of hypoxia on HBSMCs differentiation}

Wiafe et al. found evidences in favor of HBSMCs dedifferentiation, as demonstrated by the increased expression of $\alpha$-smooth muscle actin, vimentin, and desmin, and acquisition of a profibrotic phenotype [35]. Pro-fibrotic changes included the upregulation of SMAD 2, SMAD 3, and connective tissue growth factor (CTGF) genes as well as collagens 1, 2, 3, and 4, fibronectin, aggrecan, and TIMP-1 transcripts [35]. Collagen 1 transcripts exhibited a consistent increase over the entire time course, with a 3.4-fold increase after $2 \mathrm{~h}$ eventually reaching a maximum fold increase of 12 by $72 \mathrm{~h}$. Collagen 2 transcript levels showed a 4-fold increase by $72 \mathrm{~h}$; collagen 3 exhibited a similar increase, although a 5-fold increase was evident at 48 and $72 \mathrm{~h}$. Collagen 4 transcripts rose by almost 8 -fold following $72 \mathrm{~h}$ hypoxia. Total secreted collagen remained at control values until $24 \mathrm{~h}$ at which point levels rose by $100 \%$ and values remained consistently elevated during prolonged hypoxia. Fibronectin transcripts showed a consistent increase from 1.9 to 3.9-fold for values between 24 and $72 \mathrm{~h}$.

\section{Effects of hypoxia on inflammatory pathways}

Wiafe et al. demonstrated that hypoxia can produce a robust inflammatory response in isolated HBSMCs [35]. Indeed, hypoxia induced increased expression of TNF $\alpha$, IL $1 \beta$, and IL 6 which are all part of the acute phase proteins secreted in response to inflammation. Transcript levels of the anti-inflammatory cytokine, IL-10 exhibited a consistent decline [35].

\section{Other SMCs molecular alterations}

Boopathi et al. demonstrated the loss of caveolin-1, a protein that has a pivotal role in regulating SMCs contractile activity, in bladder wall smooth muscle from BPO subjects [38].

\section{Alterations occurring in the neuronal compartment}

We identified four studies describing BOO-induced morphological alterations involving bladder innervation and two studies investigating the potential role of tissue nerve growth factor (Table 3). Golsin et al. found a 56\% reduction in the number of acetylcholine-positive nerves in the specimens from obstructed bladder with respect to controls [39]. Cumming et al. confirmed the significant reduction of detrusor innervation in bladder biopsies from patients with urodynamic confirmed BOO [40]. Interestingly, innervation level was normalized in $80 \%$ of patients after $\mathrm{BOO}$ relief. Chapple et al. demonstrated a reduction in the density of innervation by vasoactive intestinal polypeptide, calcitonin gene-related peptide, substance $\mathrm{P}$ and somatostatin-immunoreactive but not neuropeptide Y-immunoreactive nerve fibers in bladder specimens from BOO patients [41]. Elbadawi et al. showed axon degeneration at electron microscopy in
Table 3 Summary of studies evaluating BOO-induced neuronal alterations

\begin{tabular}{|c|c|c|c|}
\hline Author, year & Study design & $\begin{array}{l}\text { Subjects in the } \\
\text { cases group (n) }\end{array}$ & Findings \\
\hline $\begin{array}{l}\text { Gosling, } \\
1986 \text { [39] }\end{array}$ & Case-control & 19 & $\begin{array}{l}\downarrow \text { autonomic } \\
\text { nerve supply }\end{array}$ \\
\hline $\begin{array}{l}\text { Chapple, } \\
1992[41]\end{array}$ & Case-control & 19 & $\begin{array}{l}\downarrow \text { density of } \\
\text { innervation by } \\
\text { vasoactive } \\
\text { intestinal } \\
\text { polypeptide, } \\
\text { calcitonin } \\
\text { gene-related } \\
\text { peptide, } \\
\text { substance P and } \\
\text { somatostatin } \\
\text { immunoreactive } \\
\text { nerve fibers in } \\
\text { the obstructed } \\
\text { bladder. }\end{array}$ \\
\hline $\begin{array}{l}\text { Cumming, } \\
1992 \text { [40] }\end{array}$ & Case-control & 10 & \innervation \\
\hline $\begin{array}{l}\text { Elbadawi, } \\
1993 \text { [12] }\end{array}$ & Case control & 7 & $\begin{array}{l}\text { } a x o n \\
\text { degeneration in } \\
\text { patients with } \\
\text { impaired } \\
\text { detrusor } \\
\text { contractility }\end{array}$ \\
\hline $\begin{array}{l}\text { Steers, } 1991 \\
\text { [42] }\end{array}$ & Case-control & - & $\begin{array}{l}\uparrow \text { NGF in grossly } \\
\text { hypertrophied } \\
\text { human bladders }\end{array}$ \\
\hline $\begin{array}{l}\text { Barbosa, } 2017 \\
{[37]}\end{array}$ & Case-control & 43 & $\begin{array}{l}\uparrow \text { NGF receptor } \\
\text { expression in } \\
\text { smokers and } \\
\text { dyslipidemic } \\
\text { patients }\end{array}$ \\
\hline
\end{tabular}

NGF nerve growth factor

specimens of patients who had impaired detrusor contractility [12]. The role of tissue nerve growth factor, a key signal in the regulation of nerve physiology, is controversial. Steers et al. found that the amount of nerve growth factor in grossly hypertrophied human bladders exceeded that in non-hypertrophied samples [42]. In the study by Barbosa et al. the levels of nerve growth factor and of nerve growth factor receptor in bladder tissue from the overall BPO population were not different with respect to controls [37]. However, the levels of nerve growth factor receptors were higher in the subgroup of smokers and dyslipidemic BPO patients [37].

\section{Discussion}

To our knowledge, we performed the first systematic review of studies investigating BOO-induced morphological and molecular alterations in human bladder. Data summarized demonstrate the occurrence of a remodeling process involving multiple cellular compartments, namely urothelium, suburothelium, detrusor SMCs, detrusor ECM, and neurons. Based on evidences from invitro HBSMCs cultures, cyclical stretch, increased 
pressure and hypoxia can modulate several signaling pathways potentially involved in this process. Taken together, these data support the hypothesis that the natural history of BOO may be characterized, also in humans, by three morpho-functional stages: an initial hypertrophy phase, a subsequent compensation, and a late decompensation (Fig. 2). Increased intravescical pressure during bladder voiding, the pathognomonic urodynamic feature of $\mathrm{BOO}$, can be considered the "primum movens". Indeed, it can stimulate compensatory SMCs hypertrophy and proliferation as demonstrated by in vitro studies. Tissue hypoxia subsequently intervenes as further critical stress factor. It is due to the imbalance between increased oxygen demand and lower oxygen delivery and may arise early in the natural history of BOOinduced bladder remodeling. Clinically, detrusor hypoxia has been confirmed in studies on human subjects with evidence of BOO [45-47]. Compensatory responses to hypoxia have been demonstrated in several human tissues, including the bladder. These include hypoxiainduced pathways such as HIF and VEGF. Available data suggest that, similar to animal models, these adaptive responses may counteract hypoxia only for a limited period of time. Persistent hypoxia also inhibits HBSMCs proliferation thus favoring the transition from the hypertrophy to the compensation phase, and activates signaling involved in ECM remodeling and collagen accumulation that characterize the transition from compensation to decompensation. Indeed, increased deposition of collagen and elastin in the interfascicular and intrafascicular detrusor compartments can alter the bio- mechanical properties of the bladder causing decreased compliance and impaired voiding function, which are feature considered by some authors as clinical marker of decompensation. Results from the present review have relevant clinical implications. In recent years evidences have emerged demonstrating that LUTS/BPO represent a progressive disorder in many patients [48-50]. Progression, however, has been defined based on clinical parameters such as deterioration of symptoms and healthrelated quality of life, decreased urinary peak flow rate, increased prostate size, and unfavorable outcomes such as AUR and BPE-related surgery [48-50]. Based on the results from the present study, clinicians should be aware of the fact that, beyond subjective symptoms, $\mathrm{BPO}$ also causes progressive morphological remodeling of the bladder with potential serious functional impairments. Consequently, this aspect should be carefully taken in account in the management of these patients and therapeutic outcomes should include not only the improvement of subjective symptoms but also the prevention of pathologic bladder remodeling. Evidences summarized in the present review suggest the existence of multiple signaling pathways that can represent potential targets for future therapies. Meantime, increased bladder pressure is the only pathophysiological mechanism that can be realistically improved in everyday clinical practice. Although multiple treatment options are available to treat LUTS/BPO, only surgery, alpha-1 adrenergic antagonists and 5-alpha reductase inhibitors have been reported to improve $\mathrm{BOO}$ by reducing bladder pressures. The progressive model of bladder remodeling

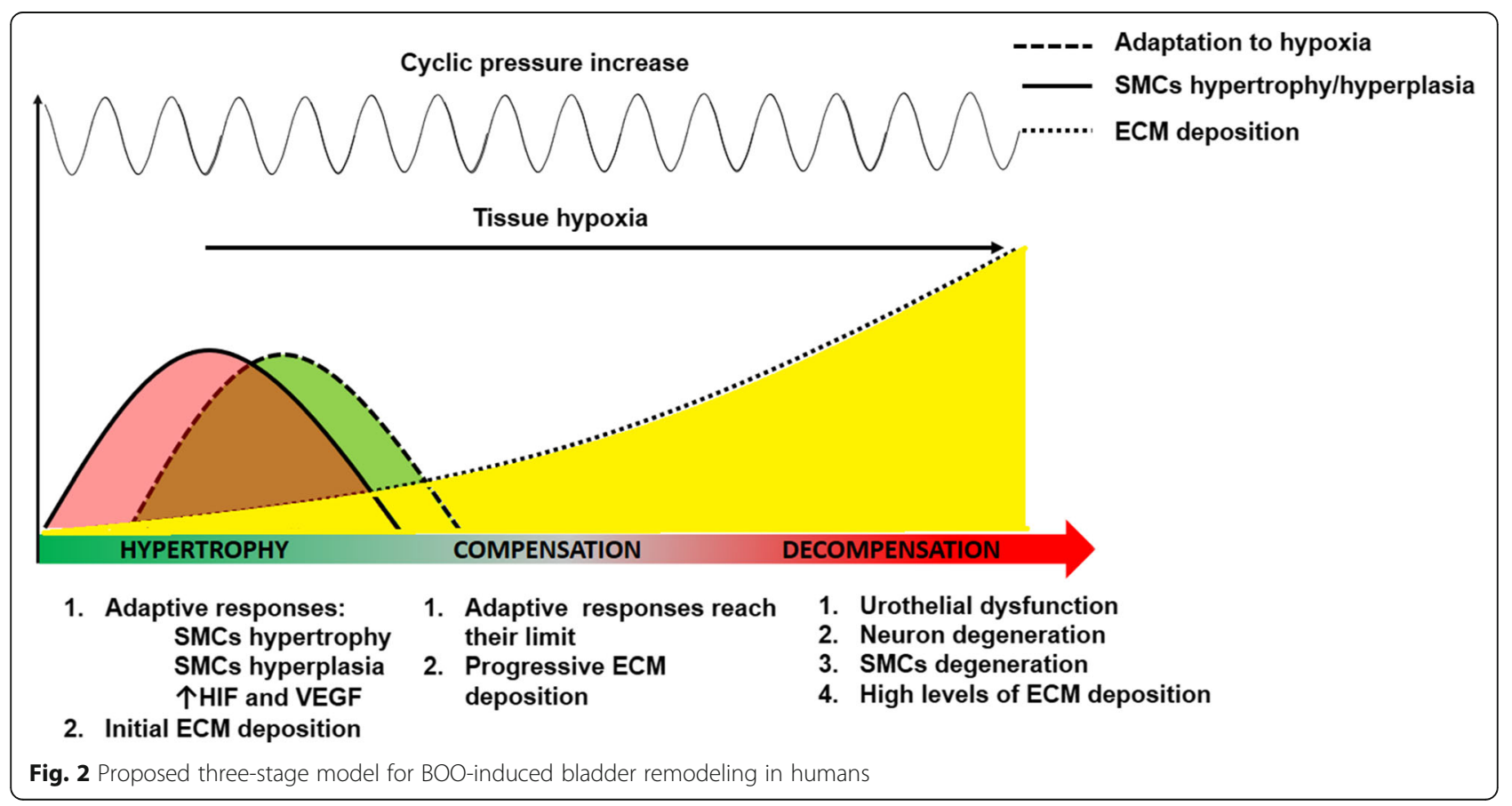


emerged from evidences summarized in the present study also contributes to explain the failures of surgical and medical therapies when prescribed later in the natural history of BOO and suggests to intervene early [48-50]. Although adherence to medical therapy for LUTS/BPO has been reported to prevent clinical disease progression the advantages in terms of morphological remodeling deserve further investigations [51]. At time, only few clinical markers of morphological bladder remodeling are available including increased estimated bladder weight and endoscopic evidence of bladder trabeculation. The role of bladder biopsies is controversial [44]. Results from the present study provide the basis for future investigations about urinary and/or serum markers of bladder remodeling. Some limits of the present study should be acknowledged: studies included are often outdated and enrolled a limited number of patients. Cultured cells may differ from fresh detrusor tissues as potential interactions among various compartments are not considered and cells are simply exposed to a single stress factor. Consequently, the molecular mechanism of bladder remodeling in $\mathrm{BOO}$ remains unclear and it remains difficult to establish an integrated signaling pathway. Further issues deserving investigations are the timing and the reversibility of BOOinduced bladder remodeling.

\section{Conclusions}

Evidences from available studies on human tissues demonstrate that $\mathrm{BOO}$ induces molecular and morphological alterations in multiple bladder compartments, namely urothelium, suburothelium, detrusor SMCs, detrusor ECM, and neurons. Cyclic stretch, increased pressure and hypoxia have been demonstrated to modulate multiple signaling pathways involved in these processes. A threestages model can be hypothesized to characterize BOOinduced bladder remodeling also in humans: hypertrophy, compensation, decompensation.

\section{Abbreviations \\ AUR: Acute urinary retention; BOO: Bladder outlet obstruction; BPE: Benign prostatic enlargement; BPO: Benign prostatic obstruction; C/M: Connective Tissue-to-Smooth Muscle Ratio; CHP: Chronic hydrostatic pressure; CTGF: Connective tissue growth factor; ECM: Extracellular matrix; HBSMCs: Human bladder smooth muscle cells; HIF: Hypoxia inducible factor; HP: Hydrostatic pressure; IL: Interleukin; LUTS: Lower urinary tract symptoms; MMPs: Matrix metalloproteinases; PDGF: Platelet derived growth factor; SMCs: Smooth Muscle Cells; TIMP: Tissue inhibitors of metalloproteases; TNF: Tumor necrosis factor; VEGF: Vascular endothelial growth factor}

\section{Acknowledgements}

All authors belong to the Italian Society of Urodynamics (SIUD) Publication Group.

\section{Funding}

None to declare.

Availability of data and materials Not applicable.

\section{Authors' contributions}

Conception and design: FF, MC, EFA. Drafting of the manuscript: MC, FF, VLM, VI. Analysis and interpretation of data: FM, CDN, VI. Supervision: EFA, FM, CDN. We confirm that all authors read and approved the final manuscript.

Ethics approval and consent to participate Not applicable.

\section{Consent for publication}

Not applicable.

\section{Competing interests}

Ferdinando Fusco: Speaker and Consultant for Recordati, Bayer, Lilly, Pierre-Fabre. Massimiliano Creta: Consultant and medical writer for Recordati. Vincenzo Li Marzi: Invited speaker from Wellspect and Allergan. Enrico Finazzi Agrò: Consultat for Laborie, Wellspect, Allergan; Speaker honorarium from: Astellas, Coloplast, Glaxo Smith Kline, Wellspect. Cosimo De Nunzio (SE) and Enrico Finazzi Agrò (AE) are members of the editorial board of BMC Urology.

\section{Publisher's Note}

Springer Nature remains neutral with regard to jurisdictional claims in published maps and institutional affiliations.

\section{Author details}

'Dipartimento di Neuroscienze e Scienze Riproduttive ed Odontostomatologiche, Università Degli Studi Di Napoli Federico II, Via Pansini, 5, 80131 Naples, Italy. ²Dipartimento di Urologia, Ospedale Sant'Andrea, Università Degli Studi di Roma "La Sapienza", Rota, Italy. ${ }^{3}$ Dipartimento di Medicina Sperimentale e Chirurgia, Università Degli Studi di Roma "Tor Vergata", Roma, Italy. ${ }^{4}$ Dipartimento di Urologia, Ospedale Careggi, Università Degli Studi di Firenze, Firenze, Italy.

Received: 7 February 2018 Accepted: 28 February 2018

Published online: 09 March 2018

\section{References}

1. Fusco F, Creta M, Imperatore V, Longo N, Imbimbo C, Lepor H, et al. Benign prostatic obstruction relief in patients with lower urinary tract symptoms suggestive of benign prostatic enlargement undergoing endoscopic surgical procedures or therapy with alpha-blockers: a review of urodynamic studies. Adv Ther. 2017;34(4):773-83.

2. Fusco F, Palmieri A, Ficarra V, Giannarini G, Novara G, Longo N, et al. a1blockers improve benign prostatic obstruction in men with lower urinary tract symptoms: a systematic review and meta-analysis of urodynamic studies. Eur Urol. 2016;69(6):1091-101.

3. Creta M, Bottone F, Sannino S, Maisto E, Franco M, Mangiapia F, et al. Effects of alpha1-blockers on urodynamic parameters of bladder outlet obstruction in patients with lower urinary tract symptoms suggestive of benign prostatic enlargement: a review. Minerva Urol Nefrol. 2016;68(2):209-21.

4. Mirone $\mathrm{V}$, Imbimbo $\mathrm{C}$, Longo N, Fusco F. The detrusor muscle: an innocent victim of bladder outlet obstruction. Eur Urol. 2007;51(1):57-66.

5. Komninos C, Mitsogiannis I. Obstruction-induced alterations within the urinary bladder and their role in the pathophysiologyof lower urinary tract symptomatology. Can Urol Assoc J. 2014;8(7-8):E524-30.

6. Levin R, Chichester P, Levin S, Buttyan R. Role of angiogenesis in bladder response to partial outlet obstruction. Scand J Urol Nephrol Suppl. 2004;215:37-47.

7. Galvin DJ, Watson RW, O'Neill A, Coffey RN, Taylor C, Gillespie Il, et al. Hypoxia inhibits human bladder smooth muscle cell proliferation: a potential mechanism of bladder dysfunction. Neurourol Urodyn. 2004; 23(4):342-8.

8. Moher D, Liberati A, Tetzlaff J, Altman DG. PRISMA Group Preferred reporting items for systematic reviews and meta-analyses: the PRISMA statement. BMJ. 2009;339:2535.

9. Jiang $\mathrm{YH}$, Lee $\mathrm{CL}$, Kuo HC. Urothelial dysfunction, suburothelial inflammation and altered sensory protein expression in men with bladder outlet obstruction and various bladder dysfunctions: correlation with Urodynamics. J Urol. 2016;196(3):831-7. 
10. Gilpin SA, Gosling JA, Barnard RJ. Morphological and morphometric studies of the human obstructed, trabeculated urinary bladder. $\mathrm{Br} J$ Urol. 1985;57(5):525-9.

11. Collado A, Batista E, Gelabert-Más A, Corominas JM, Arañó P, Villavicencio H. Detrusor quantitative morphometry in obstructed males and controls. J Urol. 2006;176(6 Pt 1):2722-8

12. Elbadawi A, Yalla SV, Resnick NM. Structural basis of geriatric voiding dysfunction. IV. Bladder outlet obstruction. J Urol. 1993;150(5 Pt 2): 1681-95.

13. Tse V, Wills E, Szonyi G, Khadra MH. The application of ultrastructural studies in the diagnosis of bladder dysfunction in a clinical setting. J Urol. 2000; 163(2):535-9.

14. Brierly RD, Hindley RG, McLarty E, Harding DM, Thomas PJ. A prospective evaluation of detrusor ultrastructural changes in bladder outlet obstruction. BJU Int. 2003;91(4):360-4.

15. Gosling JA, Dixon JS. Structure of trabeculated detrusor smooth muscle in cases of prostatic hypertrophy. Urol Int. 1980;35(5):351-5.

16. Blatt AH, Brammah S, Tse V, Chan L. Transurethral prostate resection in patients with hypocontractile detrusor-what is the predictive value of ultrastructural detrusor changes? J Urol. 2012;188(6):2294-9.

17. Holm NR, Horn T, Smedts F, Nordling J, de la Rossette J. The detrusor muscle cell in bladder outlet obstruction-ultrastructural and morphometric findings. Scand J Urol Nephrol. 2003;37(4):309-15.

18. Rubinstein M, Sampaio FJ, Costa WS. Stereological study of collagen and elastic system in the detrusor muscle of bladders from controls and patients with infravesical obstruction. Int Braz J Urol. 2007;33(1):33-9.

19. Inui E, Ochiai A, Naya Y, Ukimura O, Kojima M. Comparative morphometric study of bladder detrusor between patients with benign prostatic hyperplasia and controls. J Urol. 1999;161(3):827-30.

20. Averbeck MA, De Lima NG, Motta GA, Beltrao LF, Abboud Filho NJ, Rigotti $C P$, et al. Collagen content in the bladder of men with LUTS undergoing open prostatectomy: a pilot study. Neurourol Urodyn. 2017;25 https://doi. org/10.1002/nau.23418.

21. Bellucci CHS, Ribeiro WO, Hemerly TS, de Bessa J Jr, Antunes AA, Leite KRM, et al. Increased detrusor collagen is associated with detrusor overactivity and decreased bladder compliance in men with benign prostatic obstruction. Prostate Int. 2017:5(2):70-4.

22. Mirone V, Imbimbo C, Sessa G, Palmieri A, Longo N, Granata AM, et al. Correlation between detrusor collagen content and urinary symptoms in patients with prostatic obstruction. J Urol. 2004;172(4 Pt 1):1386-9.

23. Yang R, Amir J, Liu H, Chaqour B. Mechanical strain activates a program of genes functionally inolved in paracrine signaling of angiogenesis. Physiol Genomics. 2008;36(1):1-14.

24. Wang Y, Wang K, Li H, Chen L, Xu F, Wu T. Effects of different sustained hydrostatic pressures on connexin 43 in human bladder smooth muscle cells. Urol Int. 2013;90(1):75-82

25. Lee SD, Akbal C, Jung C, Kaefer M. Intravesical pressure induces hyperplasia and hypertrophy of human bladder smooth musclecells mediated by muscarinic receptors. J Pediatr Urol. 2006;2(4):271-6.

26. Lee SD, Misseri R, Akbal C, Jung C, Rink RC, Kaefer M. Muscarinic receptor expression increases following exposure to intravesical pressures of $<$ or $=40 \mathrm{~cm}-\mathrm{H} 2 \mathrm{O}$ : a possible mechanism for pressure-induced cell proliferation. World J Urol. 2008;26(4):387-93.

27. Preis L, Herlemann A, Adam RM, Dietz HG, Kappler R, Stehr M. Platelet Derived Growth Factor Has a Role in Pressure Induced Bladder Smooth Muscle CellHyperplasia and Acts in a Paracrine Way. J Urol. 2015;194(6):1797-805.

28. Chen L, Wei TQ, Wang Y, Zhang J, Li H, Wang KJ. Simulated bladder pressure stimulates human bladder smooth muscle cell proliferation via the PI3K/SGK1 signaling pathway. J Urol. 2012;188(2):661-7.

29. Sun Y, Luo DY, Zhu YC, Zhou L, Yang TX, Tang C, et al. MiR 3180 5p promotes proliferation in human bladder smooth muscle cell by targeting PODN under hydrodynamic pressure. Sci Rep 2016; 9. 6:33042.

30. Sun Y, Luo D, Zhu Y, Wang K. MicroRNA 4323 induces human bladder smooth muscle cell proliferation under cyclic hydrodynamic pressure by activation of erk1/2 signaling pathway. Exp Biol Med (Maywood) 2017; 242(2):169-176.

31. Wu T, Chen L, Wei T, Wang Y, Xu F, Wang K. Effect of cyclic hydrodynamic pressure-induced proliferation of human bladder smooth muscle through Ras-related C3 botulinum toxin substrate 1, mitogen-activated protein kinase kinase 1/2 and extracellular regulated protein kinases 1/2. Int J Urol. 2012;19(9):867-74
32. Chen L, Wu T, Wei TQ, Wei X, Li SF, Wang KJ, et al. Skp2-mediated degradation of p27 regulates cell cycle progression in compressed human bladder smooth muscle cells. Kaohsiung J Med Sci. 2014;30(4):181-6.

33. Liang Z, Xin W, Qiang L, Xiang C, Bang-Hua L, Jin Y, et al. Hydrostatic pressure and muscarinic receptors are involved in the release of inflammatory cytokines in human bladder smooth muscle cells. Neurourol Urodyn. 2017;36(5):1261-9.

34. Backhaus BO, Kaefer M, Haberstroh KM, Hile K, Nagatomi J, Rink RC, et al. Alterations in the molecular determinants of bladder compliance at hydrostatic pressures lessthan $40 \mathrm{~cm}$. H2O. J Urol. 2002;168(6):2600-4.

35. Wiafe B, Adesida A, Churchill T, Adewuyi EE, Li Z, Metcalfe P. Hypoxiaincreased expression of genes involved in inflammation, dedifferentiation, pro-fibrosis, and extracellular matrix remodeling of human bladder smooth muscle cells. In Vitro Cell Dev Biol Anim. 2017;53(1):58-66.

36. Koritsiadis G, Stravodimos K, Koutalellis G, Agrogiannis G, Koritsiadis S, Lazaris $A$, et al. Immunohistochemical estimation of hypoxia in human obstructed bladder and correlation with clinical variables. BJU Int. 2008; 102(3):328-32.

37. Barbosa JABA, Reis ST, Nunes M, Ferreira YA, Leite KR, Nahas WC, et al. The obstructed bladder: expression of collagen, matrix metalloproteinases, muscarinic receptors, and Angiogenic and neurotrophic factors in patients with benign prostatic hyperplasia. Urology. 2017;106:167-72.

38. Boopathi E, Gomes CM, Goldfarb R, John M, Srinivasan VG, Alanzi J, et al. Transcriptional repression of Caveolin-1 (CAV1) gene expression by GATA-6 in bladder smoothmuscle hypertrophy in mice and human beings. Am J Pathol. 2011;178(5):2236-51.

39. Gosling JA, Gilpin SA, Dixon JS, Gilpin CJ. Decrease in the autonomic innervation of human detrusor muscle in outflow obstruction. J Urol. 1986;136(2):501-4.

40. Cumming JA, Chisholm GD. Changes in detrusor innervation with relief of outflow tract obstruction. Br J Urol. 1992;69(1):7-11.

41. Chapple CR, Milner P, Moss HE, Burnstock G. Loss of sensory neuropeptides in the obstructed human bladder. Br J Urol. 1992;70(4):373-81.

42. Steers WD, Kolbeck S, Creedon D, Tuttle JB. Nerve growth factor in the urinary bladder of the adult regulates neuronal form and function. J Clin Invest. 1991;88(5):1709-15.

43 Gheinani AH, Kiss B, Moltzahn F, Keller I, Bruggmann R, Rehrauer H, et al. Characterization of miRNA-regulated networks, hubs of signaling, and biomarkers in obstruction-induced bladder dysfunction. JCl Insight. 2017:2(2):e89560.

44 Horn T, Kortmann BB, Holm NR, Smedts F, Nordling J, Kiemeney LA, et al. Routine bladder biopsies in men with bladder outlet obstruction? Urology. 2004;63(3):451-6.

45 Belenky A, Abarbanel Y, Cohen M, Yossepowitch O, Livne PM, Bachar $\mathrm{GN}$. Detrusor resistive index evaluated by Doppler ultrasonography as a potential indicator of bladder outlet obstruction. Urology. 2003;62(4): 647-50

46 Farag FF, Meletiadis J, Saleem MD, Feitz WF, Heesakkers JP. Nearinfrared spectroscopy of the urinary bladder during voiding in men with lower urinary tractsymptoms: a preliminary study. Biomed Res Int. 2013;2013:452857.

47 Macnab AJ, Shadgan B, Stothers L, Afshar K. Ambulant monitoring of bladder oxygenation and hemodynamics using wireless nearinfraredspectroscopy. Can Urol Assoc J. 2013;7(1-2):E98-E104.

48 Roehrborn CG. 5-alpha-reductase inhibitors prevent the progression of benign prostatic hyperplasia. Rev Urol. 2003;5(Suppl 5):S12-21.

49 Roehrborn CG. Alfuzosin $10 \mathrm{mg}$ once daily prevents overall clinical progression of benign prostatic hyperplasia but not acute urinary retention: results of a 2-year placebo-controlled study. BJU Int. 2006;97(4):734-41.

50 Fusco F, Arcaniolo D, Creta M, Piccinocchi G, Arpino G, Laringe M, et al. Demographic and comorbidity profile of patients with lower urinary tract symptoms suggestive of benign prostatic hyperplasia in a real-life clinical setting: are 5-alpha-reductase inhibitor consumers different? World J Urol. 2015;33(5):685-9.

51 Cindolo L, Pirozzi L, Fanizza C, Romero M, Tubaro A, Autorino R, et al. Drug adherence and clinical outcomes for patients under pharmacological therapy for lower urinary tract symptoms related to benign prostatic hyperplasia: population-based cohort study. Eur Urol. 2015 Sep;68(3):418-25. 